\title{
IMPLEMENTASI SOROGAN DALAM \\ PEMBELAJARAN AL-QUR'AN PADA \\ MADRASAH DINIYAH TAKMILIYAH
}

\author{
Muhammad Musodiqin \\ Pengasuh Madrasah Diniyah Takmiliyah Faidlul Barokat \\ Difla Nadjih \\ FAI UCY \\ Taufik Nugroho \\ FAI UCY
}

\begin{abstract}
Sorogan method is the main learning strategy in Islamic boarding schools, including when teaching the Koran. The implementation was not very different from the Madrasah Diniyah (Primary School established by the ministry of religious affairs in 1964 to study only Islamic religious sciences), especially in the Diniyah Takmiliyah Faidlul Barokat Madrasah (MDTFB). The results of the study indicate that there have been efforts made by caregivers to overcome the inhibiting factors of the Koran's learning and to consider its supporting factors. Suggestions intended for each student, parent guardian and caregiver teacher can then be given.
\end{abstract}

Keywords: Learning, al-Quran, sorogan method, madrasah diniyah takmiliyyah

Abstrak: Metode sorogan adalah strategi pembelajaran pokok dalam pembelajaran di pesatren termasuk saat pengajaran al-Quran. Pelaksanaannya ternyata tidak berbeda jauh di Madrasah Diniyah, terutama di MDTFB. Hasil penelitian menunjukkan bahwa setelah ada upaya-upaya yang dilakukan guru pengasuh untuk mengatasi factor penghambat pembelajaran al-Quran dan mempertimbangkan faktor pendukungnya. Saran-saran yang ditujukan untuk masing-masing siswa santri, wali orang tua dan guru pengasuh kemudian bisa diberikan.

Kata Kunci: Pembelajaran, al-Quran, metode sorogan, madrasah diniyah takmiliyah

\section{A. Pendahuluan}

Madrasah Diniyah Takmiliyah (MDT) merupakan lembaga pendidikan non formal keagamaan yang dibawah binaan kementrian agama RI. Kehadirannya merupakan bentuk dari kontribusi masyarakat yang secara mandiri berpartisipasi aktif dalam menjalankan kegiatan PAI 
demi terwujudnya generasi beriman, berilmu dan berakhlaqul karimah ${ }^{1}$ dan didalamnya mengajarkan Ilmu-ilmu agama yang diselenggarakan sesuai dengan tuntutan dan aspirasi masyarakat. ${ }^{2}$

Pada hakekat tujuan didirikan Madrasah Diniyah adalah untuk memberikan ilmu-ilmu agama yang cukup kepada para santri. Eksistensi Madrasah Diniyah semakin dibutuhkan tatkala jebolan pesantren yang menyelenggarakan pendidikan formal (sistem kurikulum nasional) ternyata kurang mumpuni dalam penguasaan agama. ${ }^{3}$

Kehadiran Madrasah Diniyah Takmiliyah Faidlul Barokat di Dusun Kaliwinong Lor Desa Srikayangan Kecamatan Sentolo Kabupaten Kulon Progo D.I Yogyakarta, ini disambut oleh masyarkat dengan positif dan antusiasme yang tinggi terbukti banyak wali santri yang menitipkan putra putrinya untuk ngaji/ belajar ilmu agama di madrasah diniyah, terutama dalam penguasaan kemahiran membaca Al-Qur'an.

Peran guru untuk membimbing para santri supaya dalam penguasaan pembelajaran Al-Qur'an dan mencetak santri yang fasih dalam membaca Al-Qur'an ini sangat diperlukan. ${ }^{4}$ kemudian metode atau cara-cara untuk mengantarkan santri supaya dapat membaca Al-Qur'an dengan benar dan fasih itupun sangat diperlukan pula, maka sistem yang digunakan di MDTFB adalah menggunakan salah satu dari metode tradisional yaitu metode sorogan.

Sorogan artinya belajar secara individu dimana seorang santri berhadapan dengan seorang guru, terjadi interaksi saling mengenal antara keduanya.5 Dalam pembelajaran pesantren, Metode itu termasuk pembelajaran kitab secara individual, dimana setiap santri menghadap

${ }^{1}$ Keputusan Dirjen Pendidikan Islam no. 3201 Th. 2013, Pedoman Standar Pelayanan Madrasah Diniyah Takmiliyah. hal. 1.

2 Hasbullah, Kapita Selekta Pendidikan Islam (Jakarta : PT.Grafindo Persada, 1999), hal. 39.

3 Amin Haedari dan Ishom El-Saha, Peningkatan Mutu Terpadu Pesantren dan Madrasah Diniyah, (Jakarta : Diva Pustaka. 2004), hal. 91; Taufik Nugroho, "Analisis Manajemen Pendidikan Terhadap Kualitas Madrasah Indonesia," Jurnal Ulumuddin Volume 6, Nomor 2, Desember 2016, h. 80-87

4 Bimbingan Cara Mengajar Thoriqoh Baca Tulis Dan Menghafal Al-Qur'an Yanbu'a (Kudus : Pondok Tahfidh Yanbu'ul Qur'an, 2004), hal. 2.

5 Armai Arief, Pengantar ilmu dan Metodologi Pendidikan Islam, (Jakarta : Ciputat Press, 2002). hal. 110-200. 
secara bergiliran kepada kyai atau pembantunya untuk membaca, menjelaskan, dan atau menghafal pelajaran yang diberikan sebelumnya. ${ }^{6}$

\section{B. Metode penelitian}

Subyek penelitian kini adalah pelaksana pembelajaran al-Quran di MDTFB, yaitu 1 guru dan 2 pengurus. Data dikumpulkan dengan alat observasi, dokumentasi dan interview. analisis data dilakukan secara diskriptif kualitatif, yaitu penggambaran dengan data-data atau kalimat.7 Maksudnya adalah setelah data hasil observasi, interview, dokumentasi penulis kumpulkan lalu disusun berdasarkan urutan pembahasan yang telah direncanakan. Selanjutnya penulis melakukan interpretasi secukupnya dalam usaha memahami kenyataan yang ada untuk menarik kesimpulan.

\section{Pelaksanaan Pembelajaran Sorogan}

Pelaksanaan pembelajaran Al-Qur'an di MDTFB menggunakan metode sorogan. Prosesnya sudah berjalan kurang lebih selama 2 tahun. Metode ini diambil karena dengan pertimbangan bahwa metode ini dianggap paling berhasil dalam pembelajaran Al-Qur'an.

Sebagai rujukannya seperti apa yang telah dilaksanakan di pondok pesantren Tahfidzul Qur'an Roudlotul Jannah di Kudus Jawa Tengah membuktikan hal tersebut. Salah satu gurunya, ibu Purwanti, pernah mendalami ilmu tersebut di pesantren tersebut. Pengalaman berharga beliau diupayakan untuk ditrasfer di MDTFB.

Metode sorogan, sebagaimana dikatakan oleh ibu Purwanti, adalah model pembelajaran Al-Qur'an dengan cara setoran. Yang dimaksud dengan setoran adalah para santri melaporkan kemampuannya baik membaca teks atau hafalan kepada guru tentang kemajuan hafalannya. Guru mencermati hasil belajar santri satu persatu, yang dicermati adalah tajwidnya dan kelancaran membacanya. Perlu ditambahkan bahwa metode sorogan telah memberikan hasil yang baik dalam pembelajaran Al-

6 Abdullah Aly. Pendidikan Islam Multikultural di Pesantren (Yogyakarta : Pustaka Pelajar, 2011), hal. 165.

7 Sutrisno Hadi, Metodologi Research II ( Yogyakarta : Andi Offset, 1992 ), h. 136. 
Qur'an yang dibuktikan dengan tingkat kelancaran dan kefasihan para santri yang dimiliki.

Dalam prakteknya, pembelajaran membaca Al-Qur'an di MDTFB para santri dibatasi materi belajarnya maksimal satu halaman. Namun demikian bagi santri yang memiliki kemampuan lebih dibanding dengan teman lainnya, diperbolehkan lebih dari satu halaman bahkan dua atau tiga halaman. Sebagai sejumlah contoh tentang santri yang mempunyai nilai lebih yaitu Fadhia Nurul Khofifah, Amnur Estriyani dan Himmatul Husna ke tiga anak ini mempunyai kelancaran yang lebih dari temantemannya sehingga capaian belajarnya lebih jauh. Namun demikian perlu dicatat ada sejumlah santri yang tidak mengejar kecepatan tetapi ingin lebih hati-hati dalam membaca Al-Qur'an, dengan demikian anak-anak dengan tipe kedua ingin membaca $\mathrm{Al}$-Qur'an secara benar tidak memburu cepat atau khatam. Dengan kata lain, santri untuk tipe kedua ini, mereka ingin belajar Al-Qur'an lebih lama dan tidak instan.

Dalam Pembelajarannya, pengasuh membatasi materi yang disorogkan untuk semua santri yaitu maksimal satu halaman, bagi santri yang mempunyai kemampuan bacaannya lancar, maka diperbolehkan lebih dari satu halaman bahkan diperbolehkan sampai satu atau dua lembar seperti apa yang diberlakukan kepada siswa Fadhia Nurul Khofifah, Amnur Estriyani dan Himmatul Husna. Akan tetapi kasus Fauzali Aulia Ramadlan, walaupun dia dikategorikan sebagai santri yang bacaanya lancar dengan bukti setiap setoran pengasuh sering memberikan nilai B, dia mensorogkannya hanya satu halaman. Setelah peneliti bertanya mengapa demikian ? Jawabannya adalah karena ingin mengajinya itu benar, tidak memburu cepat khatam jadi kehati-hatian untuk sampai benar memperlukan waktu yang panjang tidak instan, kalau dalam kitab Ta'limul Muta'allim disebutkan Tulu az-zaman.

Pembelajaran diawali dengan sorogan santri yang datang lebih dahulu, setelah bel madrasah dibunyikan atau guru sudah ingin memulai pembelajaran Al-Qur'an kemudian santri duduk rapi dan pembelajarn dibuka dengan membaca do'a pembuka yaitu: شيا فتاح يا عليم الخ surat AlFatihah dan شعر كلام sampai akhir. kemudian santri duduk dengan tertib 
antri kemudian menunggu temanya yang sedang mensorogkan. Pada waktu menunggu dengan antri, santri dianjurkan untuk tadarrus terlebih dahulu pada materi yang akan disorogkan, minimal 5 kali dengan demikian akan membantu kelancaran santri pada waktu mensorogkan dihadapan guru. Selain itu, hasil observasi menunjukkan tadarrus prasorogan juga dapat menumbuhkan pada santri untuk menghargai temannya serta memberikan dorongan untuk datang ke madrasah lebih awal.

Metode sorogan di MDTFB memberikan tingkat pelayanan yang baik. Layanan tersebut berupa pemberian nilai bagi santri yang kemampuan membacanya lancar, dan hampir tidak ada yang kesalahan, baik panjang pendeknya atau Tajwidnya serta makhorijul hurufnya. Tak segan-segan guru memberikan nilai B. Tetapi bagi bagi santri yang kemampun membacanya kurang lancar maka akan diberi nilai C. Selain itu, kadang-kadang santri disuruh mengulangi sampai bacaannya lancar. Menurut catatan, ada santri yang mengulang hanya satu kali, tetapi banyak santri yang diminta mengulang dua sampai tiga kali. Dengan penilaian ini pengasuh dapat mengetahui kemampuan setiap santri secara individu. Selain itu, pengasuh dapat memberikan perhatian dan bimbingan khusus bagi santri yang nilainya C. Adapun perhatian tersebut berupa remedi dengan mengaji ulang/ mensorogkannya hanya setengah halaman, agar santri merasa tidak keberatan. ${ }^{8}$

Nilai lebih dari metode sorogan ada dalam pembelajaran Al-Qur'an di MDTFB. Merujuk pada pendapat Ibu Purwanti, "Guru dapat melihat dan mengetahui secara langsung kemampuan individu yakni: dalam penguasaan materi, cara membaca atau melafalkan materi dengan baik dari sudut makhrojnya, panjang pendeknya bacaan sesuai Ilmu Tajwid”.

Ia melanjutkan, "Bagi santri yang tekun dan rajin mengajinya lebih-lebih santri yang menyadari dan mengakui bahwa bacaannya belum betul, diikuti dengan tingkat ketataatan yang tinggi kepada perintah guru, hal ini akan membantu santri untuk lebih cepat faham dan mengerti

${ }^{8}$ Kartu Prestasi Santri Madrasah Diniyah Takmiliyah Faidlul Barokat 
tentang bacaan-bacaan Al-Qur'an. Dengan ketekunan ini, guru dapat menyimak, mendegarkan bacaan santri secara lebih baik. Setiap guru mendengrkan ayat pada satu huruf/kalimat saja yang kurang betul atau kurang sesuai, maka beliau langsung menegur, membimbing dan membetulkannya. Apabila ada santri yang belum mampu mengukuti standar guru, maka guru memberikan contoh bacaan yang betul, dan santri disuruh mengulang-ulang sampai betul. Melihat kenyataan itu, metode sorogan dapat memberikan manfa'at bagi santri terhadap pemahaman, baik secara tekstual atau literal.

\section{Materi pendukung Pembelajaran Sorogan}

Materi merupakan salah satu pendukung penting di suatu pembelajaran termasuk dalam pembelajaran Al-Qur'an. Supaya santri dapat membaca Al-Qur'an dengan baik yakni baca Al-Qur'an dengan tartil, maka dikenalkan metode Yanbu'a. Pada kenyataannya, Al-Qur'an bertuliskan bahasa Arab sedangkan bahasa kita adalah bahasa jawa dan bahasa Indonesia. Tentu saja hal ini tidak mudah mengajarkan Al-Qur'an kepada anak-anak non-native.

Maka dikenalkan metode Yanbu'a. Metode Yanbu'a terdiri dari jilid (pemula) sampai dengan jilid 7 (lanjut) dan Al-Qur'anul Karim. Metode ini berbeda dengan metode pembelajaran Al-Qur'an lainnya. Metode ini muncul pada tahun 2004 yang diterbitkan oleh pondok pesantren Tahfidzul Qur'an Yanbu'ul Qur'an Kudus, dibawah yayasan Arwaniyah.

Guru madrasah telah mendapat syahadah pelatihan bersama KH. Ulil Albab Arwani yang beliau sebagai pengasuh sekaligus penulis buku pedoman metode Yanbu'a. Dalam pelaksanaannya, Penggunakan metode sorogan terlebih dahulu dinyatakan lulus dalam pelatihan dan pembinaan metode Yanbu'a di pondok pesantren Al-Qur'an Wates Kulon Progo.

Untuk mendukung kemahiran atau kelancaran santri dalam membaca Al-Qur'an, peneliti melihat diantara pelajaran-pelajaran madrasah diniyah yang mendukung antara lain:

1) Pelajaran Tajwid

Mulai kelas dua Ula/Awaliyah Ilmu Tajwid sudah diajarkan. Ilmu ini merupakan salah satu ilmu yang membantu dalam proses tahsinu 
qiroatil Qur'an. Ilmu Tajwid merupakan mata pelajaran wajib di Madrasah Diniyah Takmiliyah Faidlul Barokokat, dengan demikan secara otomatis santri akan mengetahui tentang hukum-hukum bacaan dalam AlQur'an seperti Idhghom bighunnah, ikhfak, idhar dan lain sebagainya. Adapun buku pedoman Ilmu Tajwid yaitu kitab Syifaul Jinan, Tuhfatul Atfal dan juga disetiap selesai sorogan di kitab Yanbu'a dibagian bawah dan disendirikan dalam kotak paling bawah yang merupakan keterangan tersendiri, sehingga santri sudah dikenalkan dan dijelaskan mengenai tajwid sesuai dengan kemampuan santri dan jilid yang dipelajari.

2) Pelajaran yang berbasis Bahasa dan Tulisan Arab

Sesuai dengan nama madrasah diniyah adalah sekolah Agama dan dulunya terkenal dengan nama sekolah Arab, di MDTFB itu masih berlaku, hampir semua pelajaran bertuliskan Arab seperti contoh seumpama guru menulis hadis kemudian artinya ditulis dengan Arab Pegon, hal ini berlaku untuk kelas dua dan tiga kecuali kelas pemula dan kelas satu. Dengan penulisan Arab Pegon sangat membantu dan mempengaruhi kelancaran santri dalam membaca Al-Qur'an. Belajar di Madasah Diniyah santri tidak hanya dituntut agar mampu atau mahir dalam membaca Al-Qu'an saja, tetapi santri juga dapat menulis mata pelajaran dengan berbahasa Arab dengan baik seperti; pelajaran Hadis, Fiqih dan lain-lain yang semuanya betuliskan Arab. Kesemuanya itu saling terkait dan mendukung antara cara menulis yang benar dan kemampuan membaca yang baik. Perlu dicatat bahwa pertama guru menerapkan semua pelajaran harus ditulis dengan Arab itu tidak mudah, dengan perlahan-lahan, sedikit demi sekit sehingga santri pada saat ini sudah mulai faham dan senang untuk menulis Arab. Bahkan lebih dari itu, apabila madrasah ada acara lain, sehingga pelajaran sorogan ditiadakan, santri merasa kecewa. Santri disuruh tadarus dan mengaji secara individu di rumah.

3) Hafalan

Ibu Purwanti menunjukkan hafalan merupakan progam wajib, sebab di madrasah diniyah terdapat mata pelajaran Mahfudhot yang berarti hafalan-hafalan. Adapun kitab yang menjadikan pedoman dalam 
pelajaran Mahfudhot adalah kitab yang diterbitkan oleh Madrasah Tasywiquttullab Salafiyah Kudus yang berisi hadis-hadis pendek, ayat-ayat penting dan juga kalam hikmah, walaupun dalam pelaksanaan hafalan hanya dilakukan apabila pelajaran hampir selesai atau akan pulang dan untuk kuis. Siapa yang hafal diperbolehkan pulang terlebih dahulu, juga ketika pelajaran akan dimulai sebagai kelanjutan pelajaran berikutnya, kemudian hafalan sebagai bahan ujian di setiap semester, peneliti melihat progam hafalan ini kurang diminati, karena masih merasa keberatan, santri masih merasa terbebani, tetapi disetiap akan ujian semester santri mulai menghafal dan sebagian besar mereka hafal.

4) Alat peraga YANBU'A

Dari observasi diketahui ada alat peraga ini berisi dari ringkasan materi yang tulisannya diperbesar berukuran kertas A4. Sebelum pelajaran dimulai atau pada jam ke 2 untuk dibaca bersama-sama dengan tujuan untuk mempermudah pada pengenalan huruf dan membantu kelancaran membaca, lebih-lebih makhorijul huruf. Guru akan selalu memberikan contoh-contoh secara bergantian, guru membaca dan murid menirukannya, kemudian guru menjelaskan bagaimana cara melafalkan kalimat atau ayat-ayat yang benar sesuai Tajwid dan Makhrojnya, ini ditekankan pada santri yang masih jilid pemula sampai jilid 3. Setelah peneliti mengamati proses ini, peneliti menemukan kekompakan santri untuk membaca materi belajar begitu semangat, sampai suaranya terdengar ke rumah-rumah tetangga, tetapi waktunya tidak begitu lama kurang lebih antara 5 sampai 10 menit. Alat Peraga demikian seiring dengan media Big Book. Imroatun juga mengakui manfaatnya bagi membaca nyaring untuk anak-anak. 9

\section{E. Upaya Mengatasi Hambatan Pembelajaran Sorogan}

Setiap proses pembelajaran pasti ada suatu aktivitas yang mengusahakan tercapainya tujuan baik oleh guru, santri atau unsur-unsur lainnya, begitu juga setiap usaha pasti ada hambatannya, baik yang

9 Imroatun Imroatun, "Media Belajar Bigbook Bagi Pengembangan Baca Nyaring Anak Usia Dini," in Seminar Nasional Pembelajaran Baca, Tulis, Dan Hitung Tingkat Permulaan Bagi Anak Usia Dini (Serang: FTK UIN SMH Banten, 2017), 119-127 
nampak maupun yang tidak nampak, baik yang kecil maupun yang besar. Di MDTFB dalam proses melaksanakan proses pembelajaran Al-Qur'an dengan menggunakan metode sorogan sekaligus mengatasi hambatanhambatan yang ada, adapun usaha-usaha tersebut antara lain:

1. Pemanfaatan Tempat

Sarana prasarana yang baik dan nyaman itu sudah menjadikan harapan disetiap lembaga pedidikan. Di MDTFB tempat pembelajarannya masih sangat sederhana apalagi ketika musim hujan tiba, untuk menghindari suara gemuruh atau ramai di madrasah maka pelaksanaan pembelajaran di bagi dua, sebagian tetap di madrasah dan sebagian di masjid Kaliwinong.

2. Penambahan Waktu

Pelaksanaan metode sorogan memang membutuhkan waktu yang ekstra artinya tidak boleh di buat sampingan. Guru harus benar-benar menyediakan waktu yang cukup dengan kesiapan guru untuk menyimak santri satu persatu membutuhkan konsentrasi yang tinggi. Dan hal ini sangat tergantung dengan jumlah santri yang datang Apabila santri yang datang hanya 60\% dari jumlah santri, maka waktu yang dibutuhkan hanya sebentar karena hitungannya adalah per individu. Berbeda dengan metode klasikal waktu dapat disesuaikan. Selama peneliti mengamati tentang waktu yang dibutuhkan untuk menyimak pembelajaran Al-Qur'an dengan metode sorogan, guru harus menambah durasi waktu, apabila sesuai jadwal pelaksanan pembelajaran di madrsah diniyah itu dimulai dari pukul 15.30 WIB sampai pukul 17.00 WIB, maka harus guru menambah jam pelajaran sampai satu kali lipat atau 100\% sehingga pelajaran dimulai pukul 14.30 WIB dan pulang sampai pukul 17.30 WIB, bahkan kadang-kadang sampai waktu maghrib tiba. Jadi untuk mengatasi hambatan tersebut madrasah harus menambah waktu 2 jam di luar jadwal yang telah ditentukan.

\section{Mengoptimalkan Guru}

Hubungan santri dengan guru dalam pelaksanaan pembelajaran Al-Qur'an dengan metode sorogan di MDTFB diibaratka dua keping mata uang, yang keduanya tidak dapat dipisahkan lagi, dengan keterbatasan guru yang 
mengajar Al-Qur'an, setelah peneliti wawancara dengan ibu Purwanti, maka usaha beliau mengatasi hambatan ini adalah dengan mengoptimalkan proses pembelajaran, yaitu menyusun jadwal pelajaran, menyusun tata tertib dan memanfa'atkan waktu dengan sebaik-baiknya. Apabila beliau berhalangan ada atau kegiatan yang tidak bisa ditinggalkan dan kegiatan tersebut berbenturan dengan jadwal madrasah diniyah maka pembelajaran terpaksa diliburkan.

4. Konsekwensi Santri

Santri yang mengikuti pembelajaran Al-Qur'an di Madrasah Diniyah Faidlul Barokat harus mengikuti tata tertib yang sudah ditentukan oleh dewan komite madrsah diniyah. Di antara tata tertib tersebut yaitu: menjaga nama baik guru, santri dan madrsah diniyah, dan bagi santri baru harus didaftarkan dengan mengisi formulir dan membuat surat pernyataan untuk tetap belajar mengaji di madrasah selama tidak ada halangan. Bagi santri yang awalnya memang tidak berniat untuk belajar, biasanya hanya masuk ke madrasah satu atau dua kali saja dan selanjutnya sudah tidak berangkat mengaji lagi tanpa adanya keteranagan, santri yang sudah tidak masuk madrsah lebih dari satu minggu maka dinyatakan keluar madrasah. Peneliti melihat bahwa keputusan madrasah memang berat tetapi dengan demikian dapat menumbuhkan konsekwensi santri untuk rajin berangkat mengaji.

5. Menjalin Komunikasi dengan Orang Tua/Wali Santri

Orang Tua atau Wali Santri yang baik seharusnya bangga apabila punya anak yang berstatus sebagai santri, apalagi putra atau putrinya sedang belajar Al-Qur'an dimana nabi Muhammad bersabda; Sebaik-baik kalian adalah orang yang belajar Al-Qur'an kemudian mengajarkannya (kepada orang lain) maka bagi siapa saja orang yang sedang belajar AlQur'an berarti dia adalah orang yang terbaik menurut nabi Muhammd SAW. Orang tua yang belum memahami akan kewajibannya untuk mendidik anaknya, tentang agama Islam terutama belajar Al-Qur'an dan mencetak anak yang saleh sebagai penerus orang tuanya itu tidak mudah, maka perlu kerjasama antara beberapa pihak yaitu santri, guru dan orang 
tua, pada waktu peneliti melihat bentuk kerjasama atau komunikasi dengan wali santri atau orang tua berupa:

a. Bentuk Tertulis

Setiap santri baru, yang masuk di MDTFB orang tua diwajibkan mengisi formulir pendaftaran dan membuat surat pernyataan, untuk selalu taat dan bersedia mematuhi tata tertib yang berlaku di madrasah diantaranya apabila putranya tidak berangkat mengaji maka orang tuanya wajib mengijinkan.

b. Bentuk Lisan

Kerjasama berbentuk lisan biasanya dilakukan ketika ada isu-isu yang tidak menyenagkan terhadap keberadaan madrasah diniyah, maka pengasuh dan dewan komite segera mengumpulkan wali santri untuk diberi pengertian tentang sesuatu yang terjadi yang sebenarnya. Seperti halnya di madrsah melakukan kurban sendiri tidak bergabung dengan masjid, kemudian pengasuh menjelaskan bahwa tujuannya untuk melatih, mendidik dan sebagai praktikum bagi santri.

c. Bentuk Tindakan

Bagi wali santri yang memang melanggar dari pernyataannya sendiri, maka madrasah berhak untuk menggambil sikap yang jelas, kemudian memanggil wali santri untuk dimintai keterangannya.

\section{F. Penutup}

Beberapa saran bisa disampaikan bagi pelaksanaan metode sorogan dalam pembalajaran al-Quran selanjutnya. Saran dan anjuran ini ditujukan kepada pihak yang terkait langsung di MDTFB. Mereka adalah santri, wali orang tua termasuk guru pengasuh.

1. Bagi Santri

a. Santri hendaknya tetap semangat, rajin dan disiplin berangkat mengaji jangan mudah berputusasa, kesulitan dalam belajar mengaji yakinlah pasti ada jalan keluarnya yaitu dengan selalu tadarus dan rajin berangkat mengaji.

b. Santri hendaknya jangan berburuk sangka, tetapi tetap husnuddzon terhadap guru, karena guru pasti akan memberikan yang terbaik untuk santrinya. 
2. Bagi Guru

a. Guru hendaknya mengintegrasikan metode sorogan dengan metode active learming, karena kami melihat bahwa guru MDTFB mempunyai potensi untuk itu, dan keistiqomahan santri dan guru sudah mulai terjaga tinggal penggembangannya.

b. Guru hendaknya mau menerima masukan-masukan baik dari wali santri atau masyarakat selama hal itu mendukung terhadap kemajuan madrsahdiniyah.

c. Guru hendaknya selalu menjaga keistiqomahan, kesabaran dan keuletan sehingga dariapa yang di cita-citakan oleh madrasah diniyah akan tercapai.

3. Bagi Wali Santri/ Orang Tua

a. Wali Santri hendaknya selalu mendorong, memotivasi putra-putrinya untuk selalu rajin mengaji, jangan sampai menjadikan penyebab anaknya malas mengaji dan yang akan rugi adalah orang tuanya sendiri.

b. Orang Tua harus husnuddzon terhadap guru dan selalu menjalin komunikasi.

\section{Daftar Pustaka}

Aly, Abdullah. Pendidikan Islam Multikultural di Pesantren. Yogyakarta : Pustaka Pelajar, 2011.

Arief, Armai. Pengantar ilmu dan Metodologi Pendidikan Islam, Jakarta : Ciputat Press, 2002

Arwani. Ulil Albab, dkk. Bimbingan Cara Mengajar Thoriqoh Baca Tulis dan Menghafal Al-Qu'an Yanbu'a. Kudus: PP. Tahfidzul Qur'an Yanbu'a Qur'an, 2004.

Buku Induk Madrasah Diniyah Takmiliyah Faidlul Barokat

Depag RI. Panduan Teknis Progam Wajib Belajar Pendidikan Pada Pondok Pesantren Salafiyah. Jakarta: Dirjen Kelembagaan Agama Islam, 2003.

Fatahudin. Pedoman Pengajaran Membaca dan Menulis Huruf AlQur'an. Jakarta: CV. Serajaya, 1975.

Hadi, Sutrisno. Metodologi Research II. Yogyakarta : Andi Offset, 1992 .

Haedari, Amin dan Ishom El-Saha. Peningkatan Mutu Terpadu Pesantren dan Madrasah Diniyah. Jakarta : Diva Pustaka. 2004

Hasbullah. Kapita Selekta Pendidikan Islam. Jakarta : PT.Grafindo Persada, 1999.

Imroatun, Imroatun dan Difla Nadjih. "Anti-Violence Education in the Perspective of Hadith." Indonesian Journal of Islamic Early 
Childhood Education 1, no. 1 (2016): 121-130, http://journal.ppspgra.org/index.php/Ijiece/article/view/33

Imroatun, Imroatun. "Media Belajar Bigbook Bagi Pengembangan Baca Nyaring Anak Usia Dini." in Seminar Nasional Pembelajaran Baca, Tulis, Dan Hitung Tingkat Permulaan Bagi Anak Usia Dini (Serang: FTK UIN SMH Banten, 2017), 119-127

Keputusan Dirjen Pendidikan Islam nomor 3201 Tahun 2013 tentang Pedoman Standar Pelayanan Madrasah Diniyah Takmiliyah

Musaropah, Umi. "Pemberdayaan Masyarakat Dalam Penyelenggaraan Pendidikan Anak Usia Dini Berbasis Pesantren." aș-șibyan, Jurnal Pendidikan Guru Raudlatul Athfal, Vol.1, No.2, Tahun 2016, h. 177-185, http://jurnal.uinbanten.ac.id/index.php/assibyan/ article/ view/203

Nugroho, Taufik."Analisis Manajemen Pendidikan Terhadap Kualitas Madrasah Indonesia." Jurnal Ulumuddin Volume 6, Nomor 2, Desember 2016, h. 80-87.

Saebani, Beni Ahmad dan Hendra Akhdiyat. Imu Pendidikan Islam. Bandung: CV. Pustaka Setia, 2009. 
M. Musodiqin, Difla Nadjih, T. Nugroho 